\title{
Strategies and Implication of Situated Learning: An Overview
}

\author{
Bijendra Kumar
}

\begin{abstract}
Assistant professor B.Ed. Department, Dayanand Vadic College, Orai Jalaun, Uttar Predesh, India
\end{abstract}
Corresponding author: bijendrasg8@gmail.com

\begin{abstract}
Situated cognition is a theory of instruction that suggests learning is naturally tied to authentic activity, context, and culture. Situated cognition or learning is a concept advocated in social constructivist approaches and is a natural extension of the importance attached to the context, social and cultural, in which learning is believed to be born Jean Lave (1988) is often credited with starting the situated cognition movement, although its ideals are not new. John Dewey and Lev Vygotsky both advocated similar approaches for situated learning. Present paper deals with situated learning, strategies of situated learning and their implications.
\end{abstract}

Keywords: Situated Learning, Strategies, Implication

Situated cognition or learning is a concept advocated in social constructivist approaches and is a natural extension of the importance attached to the context, social and cultural, in which learning is believed to be born. Knowledge is conceived as being embedded in and connected to the situation where the learning occurs. As a consequence, thinking and knowledge that is constructed are inextricably tied to the immediate social and physical context of the learning experience. And what is learned tends to be context-bound or tied to the situation in which it is learned (Lave \& Wenger, 1991). Evidence for the situational nature of learning can be seen in numerous cases where students' school learning fails to transfer readily relevant tasks outside of school. Collin (1989), Brown (1994) chronicle how people can acquire rather sophisticated mathematical operations in one setting and yet be quite unable to apply those same operations in another setting. The theory of situated learning claims that every human thought is adapted to the environment, i.e., situated, because what people perceive, how they conceive of their activity, and what they physically do develop together (Clancey, 1997).

How to cite this article: Kumar, B. (2021). Strategies and Implication of Situated Learning: An overview. Learning Community, 12(01): 13-18. 
Pumar

Behaviourist theories and cognitive theories look at knowledge external to world, either in behaviours or internal processes and structures. On the contrary, situated learning looks at learning phenomenon in a broader and holistic perspective incorporating behaviors (actions) and cognition by recognizing the interaction between people and environment and role of situation. In other words learning is situated in the activity in which it takes place. Learning is doing.

Brown (1989) explain that knowledge is situated, being in part a product of the activity, context, and culture in which it is developed and used. Learning methods that are embedded in authentic situations are not merely useful; they are essential. Winn (1993) states that Situated learning occurs when students work on authentic tasks that take place in real world setting. Thus, situated learning what is referred to as the "apprenticeship model" is a description of learning that takes place in highly social situations. In this sense, the word "Social" refers to a situation in which two or more individuals are together and interacting in one or more of variety of different ways, but specifically in a way that encourages learning to take place for one or more of the participants.

So, in situated learning learners undertake activities which are directly relevant to the application of the learning and which take place within a culture which is familiar and in a similar context to those in which learning might be applied in the future.

\section{Situated Learning: Characteristics}

Following are the major characteristics of situated leaning-

A fundamental concept of situated learning is that all learning takes place in a specific context and context significantly impacts learning.

When learning is removed from its context, the value of knowledge and relevance of that knowledge become depreciated.

Learning which takes place in the limited setting of school may constitute situated learning. However, classroom situated learning is implicitly based on school culture while being attributed to the real world culture of practice.

Abstract concepts like mathematics can be more easily mastered when taught in real-world context than in formal context of the classroom.

Situated learning involves a practice based approach which tends to reduce gap between school based learning and real-world learning.

Because situated learning can take place in settings that are culturally and socially diverse, the learning environment can be dynamic.

Learning can occur naturally as a consequence of the learner recognizing the practical utility of knowledge conveyed as well as need to use it, to interpret, analyse and solve real world problems. 
Situated learning tends to be demand driven, either by the student or by some entity which needs or values mastery of particular skill in a specific context.

Situated learning is a collaborative process in which student interacts with other members of a community of practice.

The relationships among members of such communities tend to be peer based rather than the more formal teacher student relationship of the classroom.

As the learner's knowledge and skills increase, the role and status of the learner as a member of community gradually evolves that of novice or apprentice to expert.

Situated learning may also involve role playing or scenario based learning activities.

Assessment of situated learning is often based on degree of mastery demonstrated by the learner rather than the formal tests.

Significant transfer of learning to settings outside the learning context is possible when situated learning is properly designed.

Tacit knowledge can be best taught by situated learning.

Everyday cognition is an integral part of situated learning and refers to the process of learning to use a tool or artefact in real life situation to accomplish a real-world objective. Because this type of knowledge is associated with cues from a real-world environment, it can be more readily recalled by the learner when needed.

\section{Key Strategies for situated learning}

Situated learning is concerned with how learning occurs every day. It is not a recommendation that teaching be "situated" or "relevant." It is a theory about the nature of human knowledge, claiming that knowledge is dynamically constructed as we conceive of what is happening to us, talk and move. Especially, our conception of our activity within a social matrix shapes and constrains what we think, do, and speak. That is, our action is situated in our role as a member of a community. The common idea in the AI literature that "situated" means "in a physical setting" or "interactive" grossly distorts the psychological nature of the theory. The theory of situated learning claims that knowledge is not a thing or set of descriptions or collection of facts and rules. We model knowledge by such descriptions. But the map is not the territory: Human knowledge is not like procedures and semantic networks in a computer program. Human knowledge should be viewed as a capacity to coordinate and sequence behaviour, to adapt dynamically to changing circumstances.

Key strategies for situated learning are given as follows: (McLellan, 1986; Brown, et al. 1989; Duffy \& Cunningham, 1996; Land \& Hannafin, 2000).

Stories 
Y Kumar

Reflection

Anchored instruction

Cognitive apprenticeship

Modling

Collaboration

Coaching

Field trips

Scaffolding

Multiple practice (Mastery learning and programmed instruction)

Exploration

Articulation

Peer tutoring: In peer tutoring, students who have mastered a topic teach those who haven't. Peer tutoring sessions often provide a context in which struggling students can more easily ask questions when they don't understand something and get immediate feedback on their performance.

Cooperative Learning: In cooperative learning, students work in small groups to achieve a common goal. Cooperative learning groups vary in duration, depending on the task to be accomplished.

Reciprocal Teaching: In reciprocal teaching a classroom teacher and several students meet in a group to read a section of text, stopping periodically to discuss what they're reading. Initially the teacher leads the discussion, asking questions about the text to promote summarizing, questioning, clarifying, and predicting. But gradually, he or she turns the role of "teacher" over to different students, who then take charge of the discussion and ask one another the same kinds of questions their teacher has modelled. Eventually, students can read and discuss a text almost independently of the teacher, working together to construct its meaning and checking one another for comprehension and possible misunderstandings.

\section{Limitations}

Situated learning programs are often very time consuming to develop.

Success of situated learning often requires the participation of an active learner who is intrinsically motivated. 
While situated learning is suitable for many learning outcomes, it is not the most efficient methodology for teaching factual information or abstract complex concepts.

\section{General implications}

Ormrod, J. E. (2011) discusses the implications of situated learning as:

Children learn and remember more when they talk about their experiences.

Learners can think more effectively when they acquire the basic cognitive tools of various activities and academic disciplines.

Children should have opportunities to engage in activities that closely resemble those they will encounter in the adult world.

Children often acquire better strategies when they collaborate with adults on complex tasks.

Challenging tasks, especially when sufficiently scaffolded, are likely to foster maximum cognitive development.

Group learning activities can help children internalize cognitive strategies.

Access to expert performances and the modelling of process lead to better learning.

\section{REFERENCES}

1. Brown, A.L. 1994. The advancement of learning. Educational Researcher, 23: 4-12.

2. Brown, J.S., Collins, A. and Duguid, P. 1989. Situated cognition and the culture of learning. Educational Researcher, 18(1): 32-41.

3. Brown, A.L., Bransford, J.D., Ferrara, R.A. and Campione, J.C. 1983. Learning, remembering, and understanding. In: J.H. Flavell \& E.M. Markman (Eds.), Handbook of child psychology, Vol. 3 Cognitive development (4th ed.) (pp. 78-166). New York: Wiley.

4. Collins, A., Brown, J.S. and Newman, S. 1989. Cognitive apprenticeship: Teaching students the craft of reading, writing, and mathematics. In: L.B. Resnick (Ed.), Knowing, learning, and instruction: Essays in honor of Robert Glaser (pp. 453-494). Hillsdale, NJ: Erlbaum.

5. Duffy, T. and Cunningham, D. 1996. Constructivism: Implications for the Design and Delivery of Instruction. In D. Jonassen (Ed.), Handbook of research on educational communications and technology. New York: Simon \& Schuster.

6. Land, S., \&Hannafin, M. (2000). Student-centered learning environments. In: Jonassen, D. and Land, S. (Eds), Theoretical foundations of learning environments. Mahwah, NJ: Lawrence Erlbaum Associates.

7. Lave, J. 1988. Cognition in practice: Mind, mathematics, and culture in everyday life. Cambridge, UK: Cambridge University Press.

8. Lave, J. and Wenger, E. 1991. Situated learning: Legitimate peripheral participation. Cambridge, MA: Cambridge University Press. 
Y Kumar

9. McLellan, H. 1986. Situated learning: Multiple perspectives. In: H. McLellan, (Ed.), Situated learning perspectives (5-18). Englewood Cliffs, NJ: Educational Technology Publications.

10. Ormrod, J.E. 2011. Human learning ( $6^{\text {th }}$ ed.). USA: Pearson Education Inc.

11. Pritchard, A. and Woollard, J. 2010. Psychology for the classroom : constructivism and social learning, Routledge taylor and Francis Group, New York.

12. Winn, W. 1991. Learning from maps and diagrams. Educational Psychology Review, 3: 211-247.

13. Winn, W. 2002. Current trends in educational technology research: The study of learning environments. Educational Psychology Review, 14: 331-351. 